\title{
NASCAR Sponsorship And Shareholder Return: Some Preliminary Results
}

William L. Huth, (E-mail: whuth@uwf.edu), University of West Florida

\begin{abstract}
NASCAR sponsorship is a major investment for corporations that choose it as a marketing communication tool. Companies frequently spend in excess of $\$ 10$ million to sponsor a car in the Nextel Cup series. This paper develops a return on investment measure for that spending using the financial market event study methodology where race day performance influence on publicly traded sponsoring firm's stock returns is examined. Results for the 2005 NASCAR Nextel Cup season suggest that sponsorship of top 5 finishing cars generates significant positive returns for the sponsoring company shareholders.
\end{abstract}

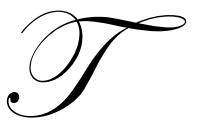

here has been a surge of interest in corporate event sponsorships as a media tool in brand development. Clancy and Krieg (2006) suggested corporate sponsorships as the new paradigm for corporate message delivery as they noted a significant shift away from traditional media outlets. They also developed a conceptual model of the linkages between sponsorship and both sales and brand equity and then considered the development of a number of methods that might provide empirical support for the contribution that sponsorship makes to the firm. Clancy and Kreig also suggested some ad hoc mechanisms for measuring the actual return to the corporation from sponsorship.

A different measurement of the value of sponsorship was developed by Cornwell, Pruitt, and Van Ness (2001). They examined the sponsorship value of winning in motorsports by looking at sponsor equity market response to winning at the Indianapolis 500. Their results were disappointing and did not support the hypothesis that winning contributed to sponsoring firm value. In a follow on project, Pruitt, Cornwell, and Clark (2004) explicitly examined NASCAR sponsorship announcements from a shareholder perspective and concluded significant wealth effects to the sponsoring firms at the initial sponsorship announcement date.

Significant financial resources have been devoted to sponsorship marketing designs. In the NASCAR Nextel Cup auto racing series, it has been documented that primary sponsors pay between 10 and 20 million dollars (NASCAR, 2004). That level of financial capital spending should provide a measurable contribution to firm profitability resulting from the sponsorship investment. That investment, like any other capital investment, should generate an expected cash flow over time that is discounted and incorporated into the present value of the firm. In the case of a race car sponsorship, the benefit flow is subject to uncertainty as the race season consists of many contests where a set of vehicles, drivers, and teams (a strategic combination of more than one vehicle) all vie for the Cup and generate different exposures to for sponsoring firms. Each contest produces winners, losers, and also-rans (not to mention accidents). The process results in significant media exposure for the sponsoring entity (most often a for profit corporation) and a benefit flow that is uncertain so that expected future returns from the sponsorship are subject to a performance risk.

Rather than looking at the valuation effect from the initial NASCAR sponsorship announcement as in Pruitt et al. (2006) the approach that was used in Cornwell, et al. (2001), where winning sponsors of the Indianapolis 500 were examined, is used in this study to addresses the valuation effects from the sponsorship as each race that makes up a NASCAR series takes place. Kotari and Warner (2005. p.4) note that "In a corporate context, the usefulness of event studies arises from the fact that the magnitude of abnormal performance at the time of an event provides a measure of the (unanticipated) impact of this type of event on the wealth of the firms' claimholders. Thus event studies focusing 
on announcement effects for a short-horizon around an event provide evidence relevant for understanding corporate policy decisions."

The tenant here is that a NASCAR corporate sponsorship is an investment that generates a stream of media attention for the sponsor over the course of the race season. That media attention is transmitted into expected earnings and those earnings expectations are incorporated into the value of the firm as the sequence of race events and their results unfold. During a given race it is the sponsorship exposure that has value and we use a finish in the top five as the "event" that generates the requisite exposure. The results in Pruitt et al. (2004) assumed that the market was able to assess the net present value of the sponsorship at the time of the initial sponsorship announcement. There was a marginally significant expectation effect in their results and it may well be the uncertainty associated with how the particular sponsored car would perform over the course of a competitive season(s) that diluted the valuation effect of the announcement. With every race, sponsorship uncertainty is reduced and the valuation effect should reflect that reduction in uncertainty. An analogous situation is the expectations at the beginning of any athletic season where preseason polls are uncertain expectations that get resolved as the season begins and contests are won or lost. Thus, the hypothesis that is tested here is that top 5 sponsorship finishes in NASCAR Nextel Cup races will have no valuation effects on sponsoring firms against the alternate that top 5 finishes will have positive valuation impacts on the sponsoring firm.

The fact that Cornnwell et al. (2001) failed to find significant returns to the Indianapolis 500 winning sponsor might well be explained by the fact that it was a single race versus the sequence of reinforcing races that is NASCAR. In essence the Indy 500 sponsorship is a one time impact similar in effect to a single television commercial during a highly visible sporting event. Valuable sponsorships are those that generate a media exposure stream.

Data from the 2005 Nextel Cup series is used to measure the contribution to corporate share value from a sponsored car finishing in the top 5 for a given race event. NASCAR sponsors can be broadly classified into primary and secondary sponsors. The primary sponsor gets the most visible spots on the vehicle (and on the driver) for their message and it those sponsors who are examined here. The sponsorship is usually directed at the entire company (eg. Dupont, Lowes, etc.) or at a specific brand, product, or service(eg. Budweiser, Cingular, etc.). Not all sponsors are companies who are publicly traded. Since stock prices are required for an equity market event study we use only publicly traded companies. As a result we do not measure the impact on public sector organizations (eg. Army, National Guard, etc.) or on private or foreign held corporations (eg. Interstate Batteries, Miller, etc.). For the 2005 NASCAR Nextel Cup season there were a total of 29 different publicly traded sponsors whose vehicles finished at least once in a top 5 spot for any of the races. Those sponsors are shown in Table 1.

Table 1

NASCAR Top Five Finisher Sponsorship in 2005 Nextel Cup Races

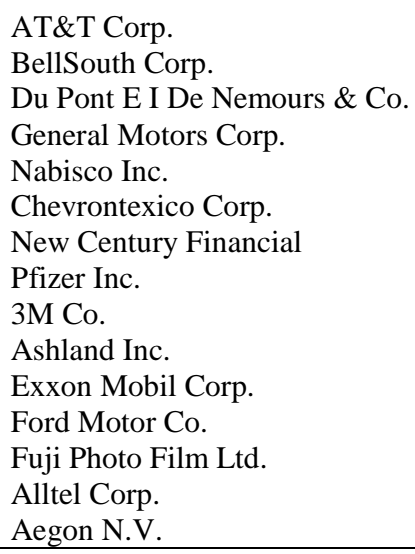


NASCAR currently consists of three series of races. The Nextel Cup series (formerly the Winston Cup) is the most prestigious of the three and it is that series that is examined for valuation effects. For the most part, sponsors choose only one series to support (a few, like Lowes, do support vehicles in multiple series). The Nextel Cup is a series of 36 races ( 37 if the all-star race is counted but this race does not fit into the driver standings computation and because there is corporate visibility generated that particular race is included) at various racetracks throughout the United States. Each race consists of 43 vehicles and each vehicle (and driver) has a primary sponsor. There are various racing teams that consist of a subset of vehicles that often race with a particular strategy for placing the individual team cars in the finish. The Nextel Cup series begins in February with the Daytona 500 and ends in November with the Ford 400 at the Homestead-Miami Speedway. The complete series of races for 2005 is in Table 2.

Table 2

Nextel Cup Series Races 2005

\begin{tabular}{|c|c|c|}
\hline $\begin{array}{l}\text { Race Day } \\
02|20| 2005\end{array}$ & $\begin{array}{l}\text { Event Day } \\
20050222\end{array}$ & $\begin{array}{l}\text { Race and Venue } \\
\text { Daytona 500, Daytona Int'1 Speedway }\end{array}$ \\
\hline $02|27| 2005$ & 20050228 & Auto Club 500, California Speedway \\
\hline $03|13| 2005$ & 20050314 & UAW-DaimlerChrysler 400, Las Vegas Motor Speedway \\
\hline $03|20| 2005$ & 20050321 & Golden Corral 500, Atlanta Motor Speedway \\
\hline $04|03| 2005$ & 20050404 & Food City 500, Bristol Motor Speedway \\
\hline $04|10| 2005$ & 20050411 & Advance Auto Parts 500, Martinsville Speedway \\
\hline $04|17| 2005$ & 20050418 & Samsung/RadioShack 500, Texas Motor Speedway \\
\hline $04|23| 2005$ & 20050425 & Subway Fresh 500, Phoenix International Raceway \\
\hline $05|01| 2005$ & 20050502 & Aaron's 499, Talladega Superspeedway \\
\hline $05|07| 2005$ & 20050509 & Dodge Charger 500, Darlington Raceway \\
\hline $05|14| 2005$ & 20050516 & Chevy 400, Richmond International Raceway \\
\hline $05|21| 2005$ & 20050523 & Nextel All-Star Challenge, Lowe's Motor Speedway \\
\hline $05|29| 2005$ & 20050531 & Coca-Cola 600, Lowe's Motor Speedway \\
\hline $06|05| 2005$ & 20050606 & MBNA RacePoints 400, Dover International Speedway \\
\hline $06|12| 2005$ & 20050613 & Pocono 500, Pocono Raceway \\
\hline $06|19| 2005$ & 20050620 & Batman Begins 400, Michigan International Speedway \\
\hline $06|26| 2005$ & 20050627 & Dodge/Save Mart 350, Infineon Raceway \\
\hline $07|02| 2005$ & 20050705 & Pepsi 400, Daytona International Speedway \\
\hline $07|10| 2005$ & 20050711 & USG Sheetrock 400, Chicagoland Speedway \\
\hline $07|17| 2005$ & 20050718 & New England 300, New Hampshire International Speedway \\
\hline $07|24| 2005$ & 20050725 & Pennsylvania 500, Pocono Raceway \\
\hline $08|07| 2005$ & 20050808 & Allstate 400 at the Brickyard, Indianapolis Motor Speedway \\
\hline $08|14| 2005$ & 20050815 & Sirius at the Glen, Watkins Glen International \\
\hline $08|21| 2005$ & 20050822 & GFS Marketplace 400, Michigan International Speedway \\
\hline $08|27| 2005$ & 20050829 & Sharpie 500, Bristol Motor Speedway \\
\hline $09|04| 2005$ & 20050906 & Sony HD 500, California Speedway \\
\hline $09|10| 2005$ & 20050912 & Chevy Rock \& Roll 400, Richmond International Raceway \\
\hline $09|18| 2005$ & 20050919 & Sylvania 300, New Hampshire International Speedway \\
\hline $09|25| 2005$ & 20050926 & MBNA RacePoints 400, Dover International Speedway \\
\hline $10|02| 2005$ & 20051003 & UAW-Ford 500, Talladega Superspeedway \\
\hline $10|09| 2005$ & 20051010 & Banquet 400, Kansas Speedway \\
\hline $10|15| 2005$ & 20051017 & UAW-GM Quality 500, Lowe's Motor Speedway \\
\hline $10|23| 2005$ & 20051024 & Subway 500, Martinsville Speedway \\
\hline $10|30| 2005$ & 20051031 & Bass Pro Shops MBNA 500, Atlanta Motor Speedway \\
\hline $11|06| 2005$ & 20051107 & Dickies 500, Texas Motor Speedway \\
\hline $11|13| 2005$ & 20051114 & Checker Auto Parts 500, Phoenix International Raceway \\
\hline $11|20| 2005$ & 20051121 & Ford 500, Homestead-Miami Speedway \\
\hline
\end{tabular}




\section{DATA AND METHODOLOGY}

The financial market event study methodology is used to compute the return to shareholders as the sponsorship is implemented and ads value throughout the race season. The event day is the first trading day following the race. Since races are generally on the weekend (Table 2 shows actual race dates and the market information "event" dates), the event date is usually a Monday although some Mondays do fall on holidays when the stock markets are closed and in those instances the event day is Tuesday. Complete details associated with the methodology are not presented here but are available in Kothari and Warner (2004). The event study methodology has become a widely accepted financial economic methodology for examining equity market reaction to information flows that might influence corporate earnings, both actual and expected. The Eventus (see, Cowan, 2005) add-in for SAS was used for all estimations and the dividend adjusted daily return data were taken from the University of Chicago CRSP daily return database. For each event day, a market model was estimated with approximately one year (255 days) of return data for the company and an equally weighted market index from a period of at least 30 days before the start of the 10 trading day time window either side of the event day. The estimated model was used to produce expected company returns using actual market index returns for each day of the 21 day event period. The estimated expected returns were compared to actual company returns for each day and the actual/expected return difference or "abnormal" return was computed for each company experiencing the event. The abnormal return for each company was accumulated across event time and test statistics for the null hypothesis that the mean abnormal return on the given day in the period was zero were computed. Because the events take place regularly over the months from February through December there is a degree of event clustering in calendar time. This clustering might induce crosscorrelation in returns violating the return independence assumption that is implicit in standard event study statistical tests of the zero abnormal return null hypothesis. That violation results in a bias towards rejection of the standard Patell Z (Patell, 1976) significance test. To account for this possibility a standardized cross-sectional test (Cowan, 2005) is also computed and reported in the empirical results that follow.

\section{EMPIRICAL RESULTS}

The results for the 2005 race series for the top 5 finishing firms are displayed in Table 3.

Table 3

Top 52005 Finisher Abnormal Returns

\begin{tabular}{ccccccc}
\hline Event Day & $\mathbf{N}$ & MAR & pos:neg & PZ & CSE t & GSZ \\
-10 & 156 & $0.06 \%$ & $76: 80$ & 0.275 & 0.629 & -0.066 \\
-9 & 156 & $-0.04 \%$ & $77: 79$ & -0.181 & -0.496 & 0.094 \\
-8 & 156 & $0.15 \%$ & $83: 73$ & $1.930^{*}$ & 1.047 & 1.055 \\
-7 & 156 & $0.00 \%$ & $73: 83$ & 0.928 & -0.033 & -0.546 \\
-6 & 156 & $-0.08 \%$ & $69: 87$ & -1.059 & -0.940 & -1.187 \\
-5 & 156 & $0.01 \%$ & $72: 84$ & 0.152 & 0.086 & -0.707 \\
-4 & 156 & $-0.04 \%$ & $73: 83$ & -0.730 & -0.365 & -0.546 \\
-3 & 156 & $0.04 \%$ & $76: 80$ & 0.609 & 0.396 & -0.066 \\
-2 & 156 & $0.11 \%$ & $70: 86$ & 1.545 & 0.893 & -1.027 \\
-1 & 156 & $0.00 \%$ & $73: 83$ & 0.138 & 0.009 & -0.546 \\
0 & 156 & $0.20 \%$ & $83: 73$ & $2.301 *$ & $1.894 *$ & 1.055 \\
1 & 156 & $0.10 \%$ & $75: 81 *$ & 1.118 & 0.959 & -0.226 \\
2 & 156 & $0.04 \%$ & $77: 79$ & 0.357 & 0.305 & 0.094 \\
3 & 156 & $0.08 \%$ & $86: 70$ & 0.905 & 0.761 & 1.536 \\
4 & 156 & $-0.14 \%$ & $63: 93$ & -1.520 & $-1.731^{*}$ & $-2.148^{*}$ \\
5 & 156 & $0.03 \%$ & $75: 81$ & 0.604 & 0.372 & -0.226 \\
6 & 156 & $-0.02 \%$ & $81: 75$ & -0.235 & -0.222 & 0.735 \\
7 & 156 & $-0.19 \%$ & $61: 95$ & $-1.869 *$ & -1.379 & $-2.468^{* *}$ \\
8 & 156 & $-0.26 \%$ & $72: 84$ & $-2.737 * *$ & -1.556 & -0.707 \\
9 & 156 & $-0.24 \%$ & $57: 99$ & $-2.363 * *$ & $-2.783 * *$ & $-3.109 * *$ \\
10 & 156 & $0.17 \%$ & $92: 64$ & $1.764 *$ & $1.973^{*}$ & $2.497^{* *}$ \\
\hline
\end{tabular}

* Significant at .05

**Significant at .01 
The table shows the 156 top 5 finishes by publicly traded corporate sponsored cars over the course of the 2005 Nextel Cup season. The mean abnormal return for the 156 companies on day zero was .20\% and that return was significantly different from zero at the 5\% (.05) level of significance as indicated by both the Patell Z (PZ) and the cross-correlation error adjusted t test (CSEt). Also on day zero, 83 of the 156 had positive average abnormal returns. The generalized sign test (GSZ) tests the null hypothesis that the fraction of positive returns on a given event day is the same as in the estimation period versus the alternate that they are different. So here there is not a significant difference between the positive return proportion over the estimation period and positive market adjusted returns on the day zero event day. Table 4 displays the abnormal

Table 4

Cumulative Abnormal Returns

\begin{tabular}{cccccc}
\hline & CAR $(\%)$ & PZ & CSEt & pos/neg & GSZ \\
$(-1,+1)$ & 0.30 & $2.05^{* *}$ & $1.54^{*}$ & $77: 79$ & 0.09 \\
$(-1,0)$ & 0.20 & $1.72^{* *}$ & $1.34^{*}$ & $73: 83$ & -0.55 \\
$(0,+3)$ & 0.42 & $2.33^{* * *}$ & $1.82^{* *}$ & $79: 77$ & 0.42 \\
\hline Note. $*, * * * * *$ & Significant at the $.10, .05, .01$ level.
\end{tabular}

returns accumulated over various event period groupings. These cumulative return groupings were one day before the event, the event day, and one day after $(-1,+1)$; one day before the event and the event day $(-1,0)$; and the event day through 3 days after $(0,+3)$ and are presented in the table. The cumulative return is displayed with the requisite test statistics and the positive negative proportion along with its significance is shown as well. All the returns were significantly different from zero at the five percent level or better except for the cross sectional error adjusted test for the day before and the event day cumulative return which was significantly different from zero at the 10 percent level. Since the event day is typically the Monday following a Sunday race day, the day zero through day +3 corresponds to the trading week prior to the start of the sequence of tasks associated with the next race (Monday through Thursday). The cumulative post race day return for 2005 top 5 finishing cars was $+0.42 \%$ and that return was significant at the five percent level or better.

\section{CONCLUSION AND FUTURE WORK}

The results here indicate significant positive abnormal returns to shareholders associated with sponsorships that produce top 5 finishes over the course of the NASCAR Nextel Cup race season. The evidence here certainly supports the contention that NASCAR corporate sponsorship ahs a significant return on investment for sponsoring company shareholders when the sponsored car is a top 5 finisher. These results significantly strengthen the preliminary findings from Pruitt et al. (2005) and Cornwell, et al. (2001). Future research efforts should be devoted to the development of a more intensive and extensive look at NASCAR sponsorship as it has developed over the years. Many other measures of exposure other than the top 5 finishers are possible and future work will focus on explaining the abnormal return for all publicly traded sponsors with specific race outcome data so that the contribution that those measures make to shareholder return can be identified and provide insight to the sponsorship decision. In addition to the Nextel series there are also other NASCAR series that can be examined for firm valuation effects (the Busch series and the Craftman Truck series). In addition other motorsport events, Formula 1 racing for example, can be examined using the event study methodology for sponsorship return on investment as well. 


\section{REFERENCES}

1. Clancy, K. and P. Krieg (2006). Go Beyond Faith When Making Decisions About Sponsorships and Events. Marketing Management (May/June).

2. Clark, J.M., Cornwell, T.B., and S.W. Pruitt (2002). Corporate Stadium Sponsorships, Signaling Theory, Agency Conflicts, and Shareholder Wealth. Journal of Advertising Research (November/December): 16-32.

3. Cornwell, T.B., Pruitt, S.W., and J.M. Clark (2005). The Relationship Between Major-League Sports' Official Sponsorship Announcements and the Stock Price of Sponsoring Firms. Journal of the Academy of Marketing Science.

4. Cornwell, T.B., Pruitt, S.W., and R. Van Ness (2001). The Value of Winning in Motorsports: Sponsorshiplinked Marketing. Journal of Advertising Research (January/February): 17-31.

5. Cowan, A. (2005). Eventus User's Guide. Retrieved from http://www.eventstudy.com

6. Kothari, S.P. and J. Warner (2005). Econometrics of Event Studies. In B.E. Eckbo, ed., Handbook of Corporate Finance: Empirical Corporate Finance. Amsterdam: Elsevier/North Holland. Chapter 1.

7. NASCAR (2004). The Cost and Value of Team Sponsorship. http://nascar.com

8. Pandey, V.K., Shanahan, K.J., and S.W. Hansen (2005). The Relationship Between Shareholder Wealth Effects, Diversity, and Publicity as a Marketing Strategy. Journal of the Academy of Marketing Science.

9. Patell, J. (1976). Corporate Forecasts of Earnings per Share and Stock Price Behavior: Empirical Tests. Journal of Accounting Research 14: 246-276.

10. Pruitt, S.W., Cornwell, T.B., and J.M. Clark (2004). The NASCAR Phenomenon: Auto Racing Sponsorships and Shareholder Wealth. Journal of Advertising Research (September):281-296.

11. Tripodi, J.A., Hirons, M., Bednall, D., and M. Sutherland (2003). Cognitive Evaluation: Prompts used to Measure Sponsorship Awareness. International Journal of Market Research (45), 4:435-454. 